\title{
3D modelling of the Onega Basin, northwestern Russia, from gravity and magnetic data and borehole information
}

\author{
Matthis Frey' ${ }^{1}$ Jörg Ebbing ${ }^{1} \&$ Aivo Lepland ${ }^{2}$ \\ ${ }^{1}$ Institut für Geowissenschaften, Christian-Albrechts-Universität zu Kiel, Otto-Hahn-Platz 1, 24118 Kiel, Germany. \\ ${ }^{2}$ Norges geologiske undersøkelse, P.O. Box 6315 Torgarden, 7491 Trondheim, Norway. \\ E-mail corresponding author (Jörg Ebbing): Joerg.Ebbing@ifg.uni-kiel.de
}

\begin{abstract}
The Palaeoproterozoic Onega Basin in northwestern Russia is an important geological archive for global events during oxygenation of Earth at 2.5-2.0 Ga. In this study, we make use of recent drilling results from the Fennoscandian Arctic Russia - Drilling Early Earth Project and the Onega Parametric Hole in combination with available gravity and magnetic data to illuminate the structure of the basin and its internal build-up. These drilling campaigns have provided new information on petrophysical properties (density, magnetic susceptibility) and stratigraphic thickness of the main horizons in the basin. We use this information in combination with gravity and magnetic data to construct a 3D crustal model of the basin with emphasis on its near-surface structure. Our near-surface structure is in agreement with previous findings and most of the gravity and magnetic anomalies are associated with known geological bodies. Modelling also suggests a lateral lithological subdivision of the upper Archaean crust into three parts. The central crust has a higher magnetic susceptibility of 0.12 (SI) and lower density of $2.7 \mathrm{~g} / \mathrm{cm}^{3}$, while the surrounding upper crust in the western and eastern edge regions has a lower magnetic susceptibility of 0.075-0.1 (SI), but a slightly higher density of 2.75-2.8 g/ $\mathrm{cm}^{3}$. One possible explanation for the differences is the presence of highly magnetised magmatic rocks in the centre of the Onega region caused by magmatic activity resulting in lava flows and comagmatic shallow intrusions during the early Palaeoproterozoic.
\end{abstract}

Keywords: gravity field, magnetic field, 3D modelling, borehole data, Onega Basin

Electronic Supplement A: Complete3D model

Received 26. April 2018 / Accepted 15. November 2018 / Published online 6. December 2018

\section{Introduction}

The Palaeoproterozoic Onega Basin is located in northwestern Russia and consists mainly of supracrustal rocks of about 2 to $2.5 \mathrm{Ga}$ (Fig. 1). These sedimentary and volcanic successions are of high interest because major global events, like the Huronian Glaciation (e.g., Symons, 1975; Young, 1991), the Great Oxidation Event (e.g., Holland, 2006) and the evolution of the aerobic Earth system took place during that era (e.g., Kump et al., 2011).
In order to understand these processes in the early Earth's history, two recent drilling projects focused on the environmental changes as recorded in the succession of the Onega Basin. The first is the Fennoscandian Arctic Russia-Drilling Early Earth Project (FAR-DEEP; Melezhik et al., 2010, 2013b) as part of the International Continental Scientific Drilling Program. In total, six boreholes were drilled in the northern and eastern part of the Onega Basin (Fig. 1) for which the lithological characteristics and the magnetic susceptibility were determined in constant vertical intervals. The second drilling project was the Onega Parametric Drillhole

Frey, M., Ebbing, J. \& Lepland, A. 2018: 3D modelling of the Onega Basin, northwestern Russia, from gravity and magnetic data and borehole information. Norwegian Journal of Geology 98, 1-12. https://dx.doi.org/10.17850/njg98-4-03. 

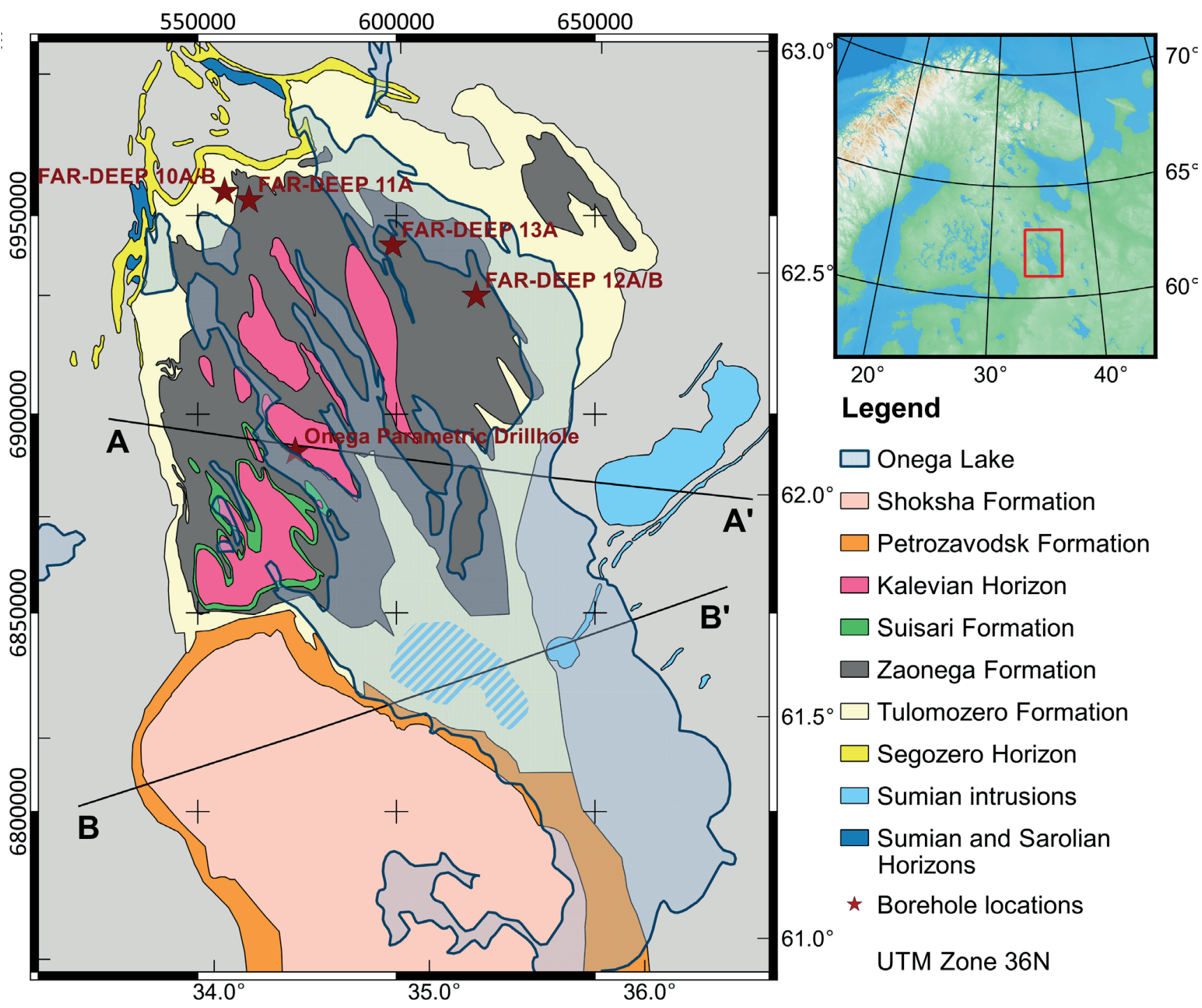

\section{Onega Lake}

$\square$ Shoksha Formation

$\square$ Petrozavodsk Formation

Kalevian Horizon

Suisari Formation

Zaonega Formation

$.5^{\circ} \square$ Tulomozero Formation

$\square$ Segozero Horizon

$\square$ Sumian intrusions

Sumian and Sarolian Horizons

$\star$ Borehole locations

UTM Zone 36N

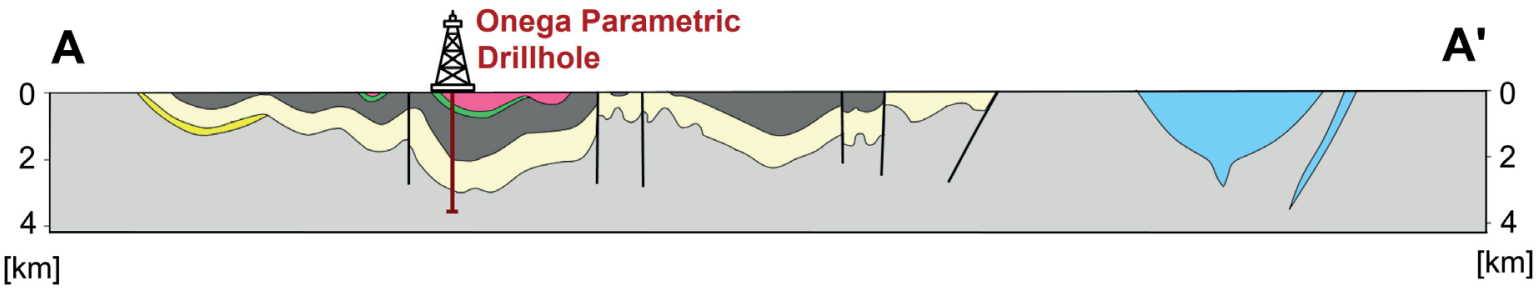

\section{B}

B'

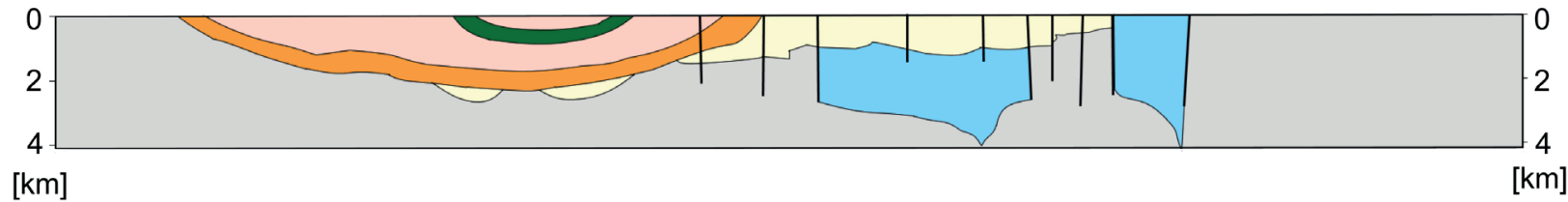

Figure 1. Upper left panel: Simplified geological map of the Onega Basin (modified after Glushanin et al., 2011) including the locations of the FAR-DEEP drilling sites and the Onega Parametric Drillhole. The red box on the overview map indicates the study area and the extent of maps shown in the remaining figures. Lower panels: Two geological profiles of the Onega Basin: A-A' intersects the northern synclinorium structure; $B-B$ ' intersects the southern trough structure (Glushanin et al., 2011). For modelling results along these profiles see Figs. 7-9. 
(OPD) located in the western part of the central basin (Fig.1), which was carried out in 2007-2009 by the Russian Geological Institute (Krupenik et al., 2011). The OPD resulted in an approximately 3500-m deep drillhole with fragmentary core recovery intersecting a $2900 \mathrm{~m}$ succession of Palaeoproterozoic volcano-sedimentary rocks and $600 \mathrm{~m}$ of underlying Archaean gneiss for which the magnetic susceptibility and the rock density were determined. All findings from the OPD and previous projects have been summarised recently by Glushanin et al. (2011) including seismic profiles, geological sections and models of the geological structure of the basin.

Here, we present a first 3D structural model of the Onega Basin that fits the observed gravity and magnetic anomalies with focus on the near-surface geology. The main aim was to obtain a comprehensive overview of the volcano-sedimentary formations where the newly available borehole data can constrain the model.

\section{Geology}

Situated in the southeastern part of the Fennoscandian Shield, the Onega Basin represents the largest intracontinental basin within the Karelian craton. It covers an area of approximately $40,000 \mathrm{~km}^{2}$ and is filled with Palaeoproterozoic sediments and magmatic rocks (Gorbatschev \& Bogdanova, 1993). The basement in the area consists primarily of Archaean granitoid gneiss of an age up to $3.2 \mathrm{Ga}$ (Slabunov et al., 2006).

\section{Palaeoproterozoic evolution}

The development of the rocks of the Fennoscandian Shield during the late Archaean and the Palaeoproterozoic occurred in several steps. In the early Palaeoproterozoic, plume-related gabbroic intrusions caused continental uplift, which resulted in crustal extension and the initiation of NW-SE-oriented continental rifting during Sumian time (Table 1). The newly formed Onega Basin was subsequently filled with polymict conglomerates and volcanic rocks. Rifting became more intense, resulting in the establishment of marine ecosystems and carbonate platforms in the Onega region (Lahtinen et al., 2008). Subsequently, calcium sulphates, dolomites and other carbonates were accumulated (Blättler et al., 2018).

The break-up of the Neoarchaean-Palaeoproterozoic Kenorland supercontinent at about $2.1 \mathrm{Ga}$, led to the formation of the new Kola Ocean and the Svecofennian Sea and the deposition of turbiditic greywackes at the continental margin. This was followed by deposition of siliciclastic and carbonate sediments, very rich in organic matter (Corg), known as the Shunga Event (Melezhik et al., 2009).

Table 1. Summary of the formations in the Onega Basin with their petrophysical properties. The typical range of the petrophysical parameters of the common rock types is given.

\begin{tabular}{|c|c|c|c|c|c|c|c|}
\hline Complex & Super-Horizon & Formation & $\begin{array}{l}\text { Occurrence } \\
\text { in the basin }\end{array}$ & Lithology & $\begin{array}{l}\text { Max. } \\
\text { Thickness }\end{array}$ & $\begin{array}{l}\text { Density } \\
{\left[\mathrm{g} / \mathrm{cm}^{-3}\right]}\end{array}$ & $\begin{array}{l}\text { Susceptibility } \\
\text { [SI] }\end{array}$ \\
\hline \multirow{12}{*}{$\frac{\sqrt[\pi]{3}}{\sqrt[\pi]{\pi}}$} & \multirow{2}{*}{$\begin{array}{c}\text { Vepsian } \\
(1800-1600 \mathrm{Ma})\end{array}$} & Shoksha & South & $\begin{array}{l}\text { Sandstones, quartzites, } \\
\text { conglomerates }\end{array}$ & $1000 \mathrm{~m}$ & $2.5-2.7$ & $10^{-5}-10^{-3}$ \\
\hline & & Petrozavodsk & South & Sandstones & $300-450 \mathrm{~m}$ & $2.5-2.7$ & $10^{-5}-10^{-3}$ \\
\hline & \multirow{2}{*}{$\begin{array}{c}\text { Kalevian } \\
(1960-1900 \mathrm{Ma})\end{array}$} & Vashozero & Center & $\begin{array}{l}\text { Sandstones, siltstones, clay, } \\
\text { conglomerates }\end{array}$ & $170 \mathrm{~m}$ & $2.5-2.7$ & $10^{-5}-10^{-3}$ \\
\hline & & Kondopoga & Center & Volcanoclastic sediments & $600 \mathrm{~m}$ & $2.5-2.8$ & $10^{-5}-10^{-2}$ \\
\hline & \multirow{2}{*}{$\begin{array}{l}\text { Ludicovian } \\
(2060-1960 \mathrm{Ma})\end{array}$} & Suisari & West & $\begin{array}{l}\text { Magmatic rocks, tuffs, } \\
\text { conglomerates }\end{array}$ & $700 \mathrm{~m}$ & $2.5-2.9$ & $10^{-3}-10^{-1}$ \\
\hline & & Zaonega & $\begin{array}{l}\text { Center, } \\
\text { north }\end{array}$ & $\begin{array}{l}\text { Corg-rich siliciclastic and } \\
\text { carbonate sediments, basalt }\end{array}$ & $800-850 \mathrm{~m}$ & $2.6-2.9$ & $10^{-3}-10^{-1}$ \\
\hline & \multirow{3}{*}{$\begin{array}{c}\text { Jatulian } \\
(2300-2060 \mathrm{Ma})\end{array}$} & Tulomozero & $\begin{array}{l}\text { Whole } \\
\text { basin }\end{array}$ & $\begin{array}{l}\text { Dolostones, sandstones, } \\
\text { evaporates }\end{array}$ & $400-800 \mathrm{~m}$ & $2.3-2.9$ & $10^{-5}-10^{-3}$ \\
\hline & & Medvezhegorsk & West & $\begin{array}{l}\text { Clastic sedimentary rocks, } \\
\text { basalts }\end{array}$ & $30 \mathrm{~m}$ & $2.5-3$ & $10^{-5}-10^{-1}$ \\
\hline & & Jangzero & West & $\begin{array}{l}\text { Sandstones, siltstones, } \\
\text { conglomerates, basalt }\end{array}$ & $45-70 \mathrm{~m}$ & $2.5-3$ & $10^{-5}-10^{-1}$ \\
\hline & $\begin{array}{c}\text { Sariolian } \\
(2430-2300 \mathrm{Ma})\end{array}$ & Paljeozero & $\begin{array}{l}\text { West, } \\
\text { north }\end{array}$ & $\begin{array}{l}\text { Conglomerates, greywackes, } \\
\text { sandstones }\end{array}$ & $450 \mathrm{~m}$ & $2.5-2.7$ & $10^{-5}-10^{-3}$ \\
\hline & \multirow{2}{*}{$\begin{array}{c}\text { Sumian } \\
(2505-2430 \mathrm{Ma})\end{array}$} & Kumsa & Kumsa area & $\begin{array}{l}\text { Magmatic intrusions, clastic } \\
\text { sedimentary rocks }\end{array}$ & $1200 \mathrm{~m}$ & $2.9-3.1$ & $10^{-3}-10^{-1}$ \\
\hline & & Glubokozero & Kumsa area & Schist, sandstone & $150 \mathrm{~m}$ & $2.5-2.7$ & $10^{-5}-10^{-3}$ \\
\hline
\end{tabular}


In the late Palaeoproterozoic, subduction of oceanic lithosphere was accompanied by high volcanic activity in island arcs. A succession of several orogenies finally led to formation of the Columbia-Hudsonia-Nuna supercontinent approximately $1.8 \mathrm{Ga}$ ago (Zhao et al., 2002; Lahtinen et al., 2008).

\section{Geological subdivision of the Onega basin}

The Onega Basin is divided into a northern synclinoriumlike part and a southern trough-like structure. The Archaean basement is overlain by six super-horizons, which are from oldest to youngest: the Sumian, Sariolian, Jatulian, Ludicovian, Kalevian and Vepsian horizons. They can be further subdivided in up to 12 formations (Kulikov et al., 2011), whose lithological characteristics are summarised in Table 1 (Melezhik et al., 2013a).

The two main geological units that are present throughout the entire basin are the Tulomozero and Zaonega formations. Their stratigraphic thicknesses are up to 800 $\mathrm{m}$ and $1500 \mathrm{~m}$, respectively (Kuznetsov et al., 2012; Črne et al., 2014). The Tulomozero Formation consists primarily of dolostones, sandstones and evaporates. In contrast, the Zaonega Formation consists of volcanoclastic sediments and organic-rich sedimentary rocks that are interlayered with mafic lava flows and comagmatic sills. Therefore, the Zaonega Formation might be considered as a source for strong magnetic anomalies (Kuznetsov et al., 2012; Melezhik et al., 2013a).

\section{Data and constraining information}

In the following, we describe the geophysical data as well as the different geological constraints used for the modelling.

\section{Gravity and magnetic data}

The free-air gravity data (Fig. 2B) were given by the DTU10 model, which has a nominal resolution of 1 arc minutes (Andersen et al., 2010). From the data, we extracted a dataset with $5 \mathrm{~km}$ station distance. The station distance is in agreement with the data used for the gravity model, which are similar to those in the EGM2008 (Pavlis et al., 2012). Although it is difficult to provide an exact assessment of the gravity data, an uncertainty of $\pm 5 \mathrm{mGal}\left(\mathrm{mGal}=10^{-5} \mathrm{~m} / \mathrm{s}^{2}\right)$ is typical for such datasets.

Next, we calculated the simple Bouguer anomaly (Fig. 2C), using topography data from the Altimeter Corrected Elevations 2-Project (Fig. 2A, Berry et al., 2010) with a correction density of $2670 \mathrm{~kg} / \mathrm{m}^{3}$. The bathymetry of the lake was not considered in the reduction as the water depth of the Onega Lake is less than 30 metres.

The values of the Bouguer anomaly are mainly in the range of $\pm 40 \mathrm{mGal}$ in the Onega region. Larger anomaly lows are located to the north and southeast of the lake. The most prominent high is an elongated NESW-trending structure in the eastern basin. Broad highs with values of about 10 to $20 \mathrm{mGal}$ are also found at the eastern and southwestern edges of the basin.

\section{A) Topography}

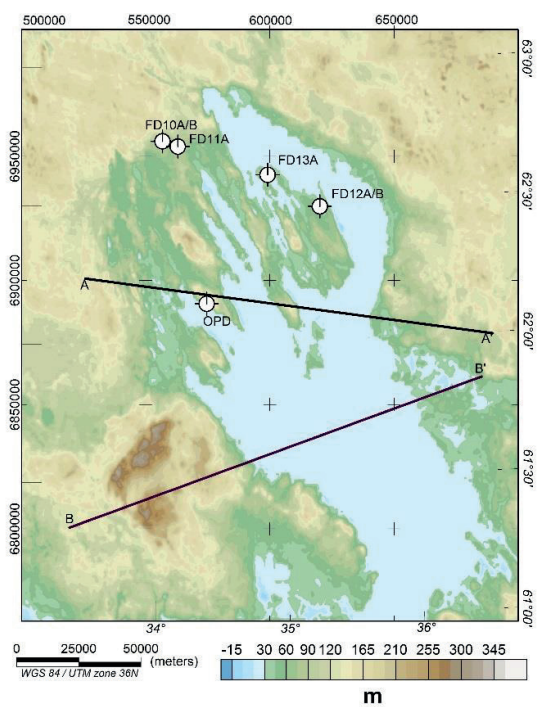

B)Free-air anomaly

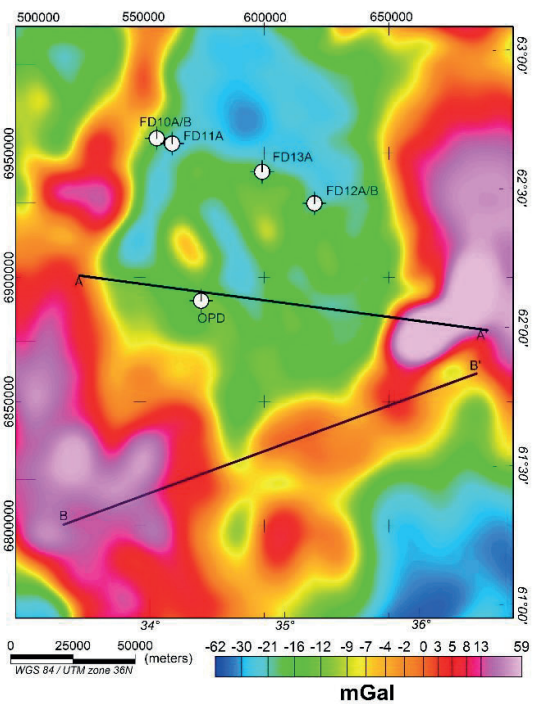

C) Bouguer anomaly

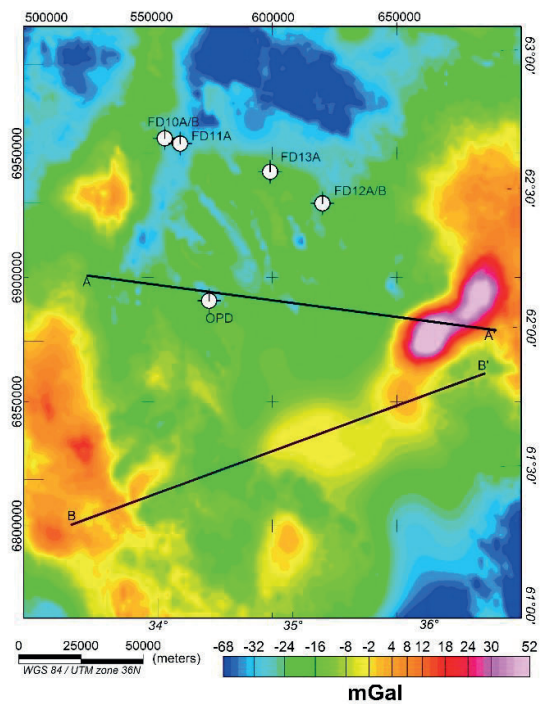

Figure 2. (A) Topography for the study area. (B) Free-air anomaly from the DTU2010 gravity model. (C) Simple Bouguer anomaly as calculated with a reduction density of 2670 kg/m3. OPD: Onega Parametric Drillhole, FDxx: Far Deep borehole locations. The profiles along lines A-A' and $B-B$ ' are shown in Figure 1. 

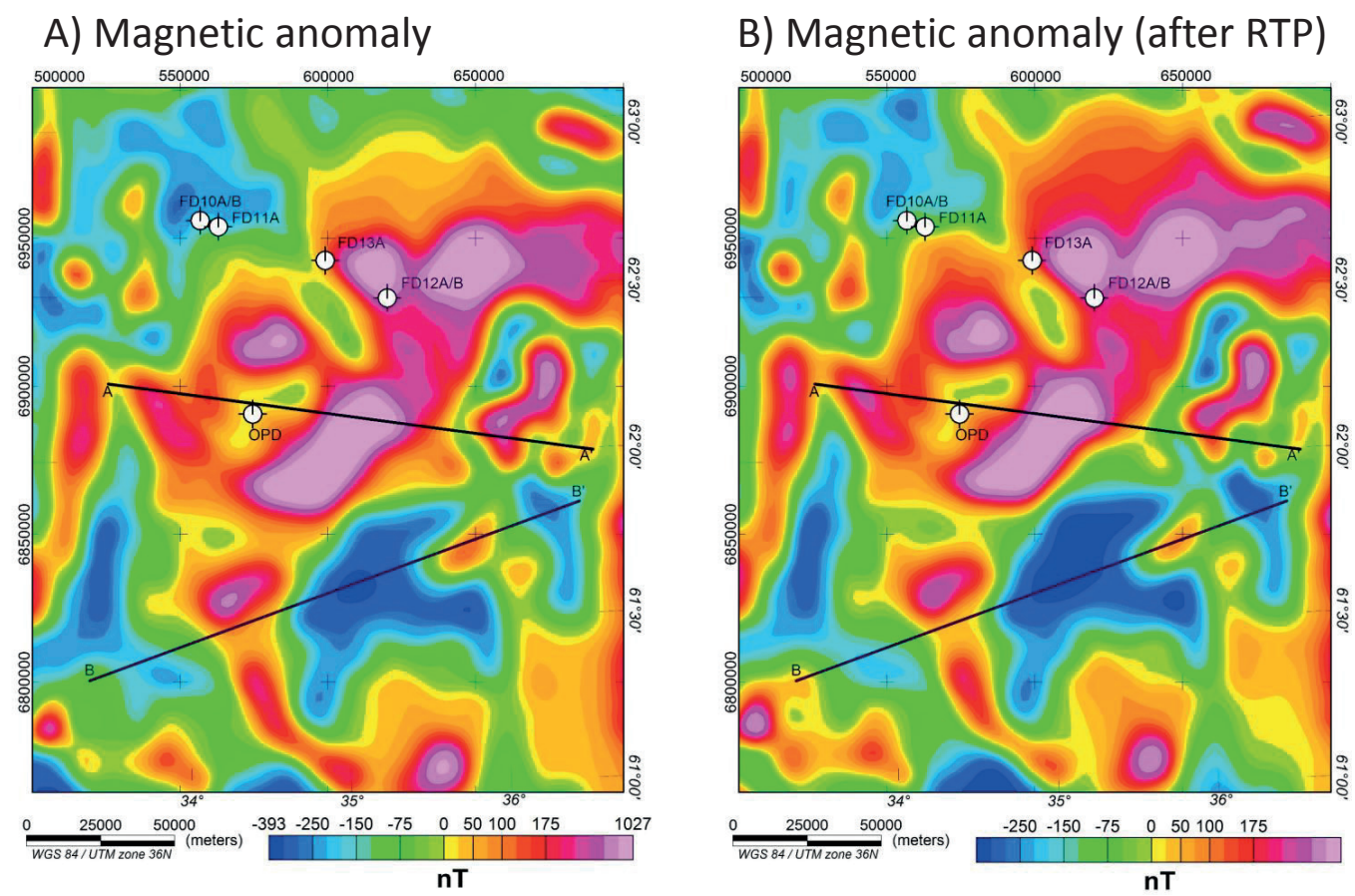

Figure 3. (A) Magnetic anomaly from the Circum-Arctic Mapping project (Gaina et al., 2001). (B) Magnetic anomaly after reduction to the pole.

For the magnetic modelling, we used data from the Circum Arctic Mapping Project (Gaina et al., 2011; Fig. $3 \mathrm{~A})$. In the project, all available magnetic measurements from the Circum-Arctic region have been combined and unified in order to compile the magnetic anomaly map. The resulting dataset has a nominal grid resolution of $2 \mathrm{~km}$ at a reference height of $1 \mathrm{~km}$ (Gaina et al., 2011). However, the anomaly maps have varying resolution and accuracy due to the quality of the available input data (Gaina et al., 2011). Fig. 3B shows the magnetic anomaly after reduction to the pole. For reduction, and later on for modelling, we used a normal magnetic field of total field intensity of $53,089 \mathrm{nT}$, a declination of $12^{\circ}$ and an inclination of $74^{\circ} 50^{\prime}$ chosen for the centre of the study area $\left(62^{\circ} \mathrm{N}, 35^{\circ} \mathrm{E}\right)$.

While the gravity anomalies are relatively subtle, the magnetic anomalies show large variations mostly within the range -300 to $+300 \mathrm{nT}$, but also from -393 to +1027 $\mathrm{nT}$. The largest magnetic high is located in the central and northeastern parts of the Onega Basin. In the northeastern, southern and central parts of the basin additional smaller anomaly highs can be identified. A magnetic anomaly low occurs in the centre of the Onega Lake and in the surroundings to the basin.

After reduction to the pole, the main anomalies are slightly shifted and the amplitudes of the highest lows and highs are even increased. In the case of dominant induced magnetisation, the reduction to the pole should shift the anomalies over the causative source body. If remanent magnetisation is present, as is likely for Archaean basement, the anomaly is still offset with respect to the source. In Fig. 4 we compare the reduced to the pole magnetic anomaly with the Bouguer anomaly to illuminate the similarities and differences between the gravity and magnetic datasets.

\section{Geological constraints}

The modelling of the shallow geology is mainly based on the geological map data and the two profiles from Glushanin et al. (2011) shown in Fig. 1. In addition, the rock records of the FAR-DEEP and the OPD cores provided important information about the thickness and petrophysical parameters of the common formations. The FAR-DEEP cores 10 to 13 in the northern and eastern parts of the Onega Basin (see Fig. 1 for locations) comprise the Tulomozero and Zaonega formations (Melezhik et al., 2010).

The $3500 \mathrm{~m}$-long OPD core contains $2900 \mathrm{~m}$ of Palaeoproterozoic volcano-sedimentary rocks of the northern synclinorium-like basin and approximately 600 $\mathrm{m}$ of the Archaean basement gneiss. A summary of the formations intersected by the drillings is given in Table 2 . Unfortunately, these drillcores do not cover all geological units occurring in the Onega basin. In particular, there is little information on the formations in the southern trough and in the Kumsa area.

There are also limited data available for the deeper geology of the region and especially for the internal structure of the crust. We used a map from Grad et al. (2009, Fig. 5) as a constraint for modelling the crustal 


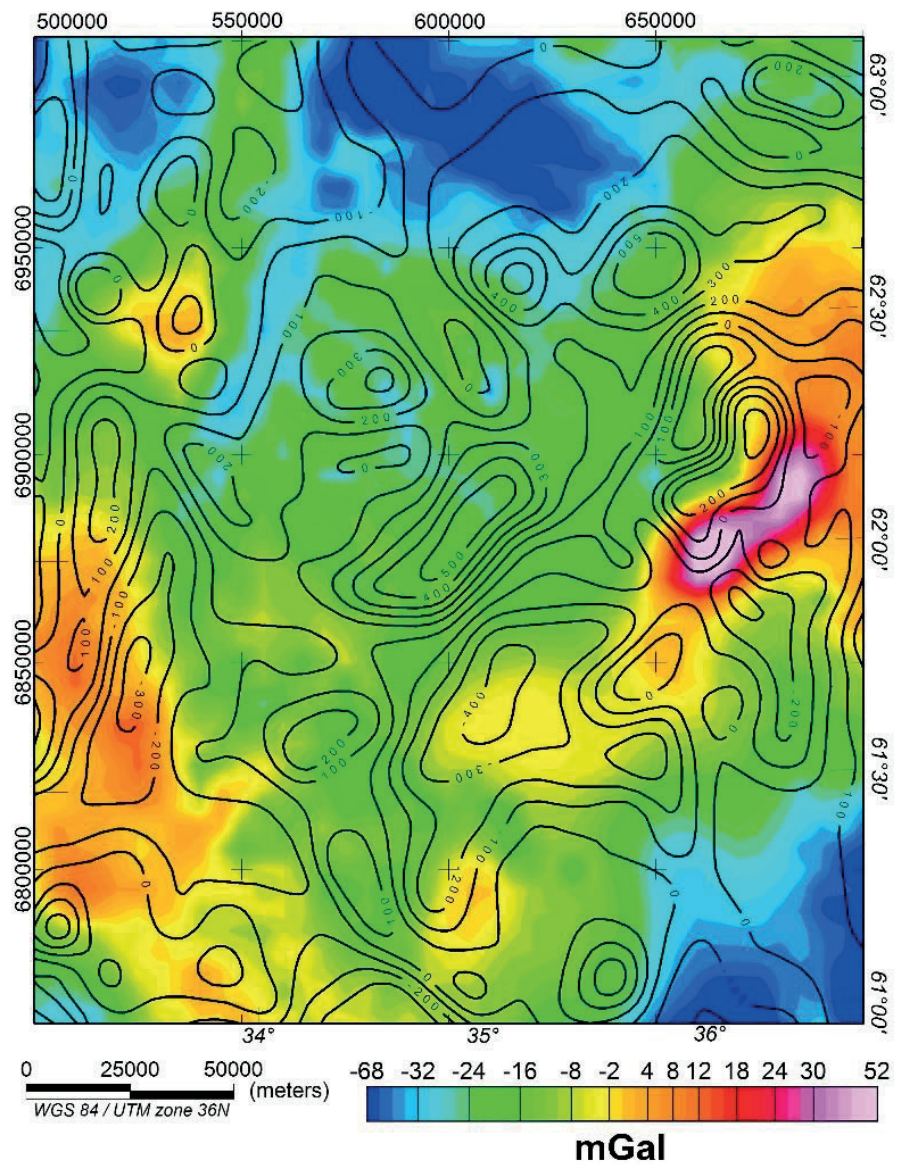

Figure 4. Contour lines of the magnetic anomaly after reduction to the pole superimposed on the Bouguer anomaly.

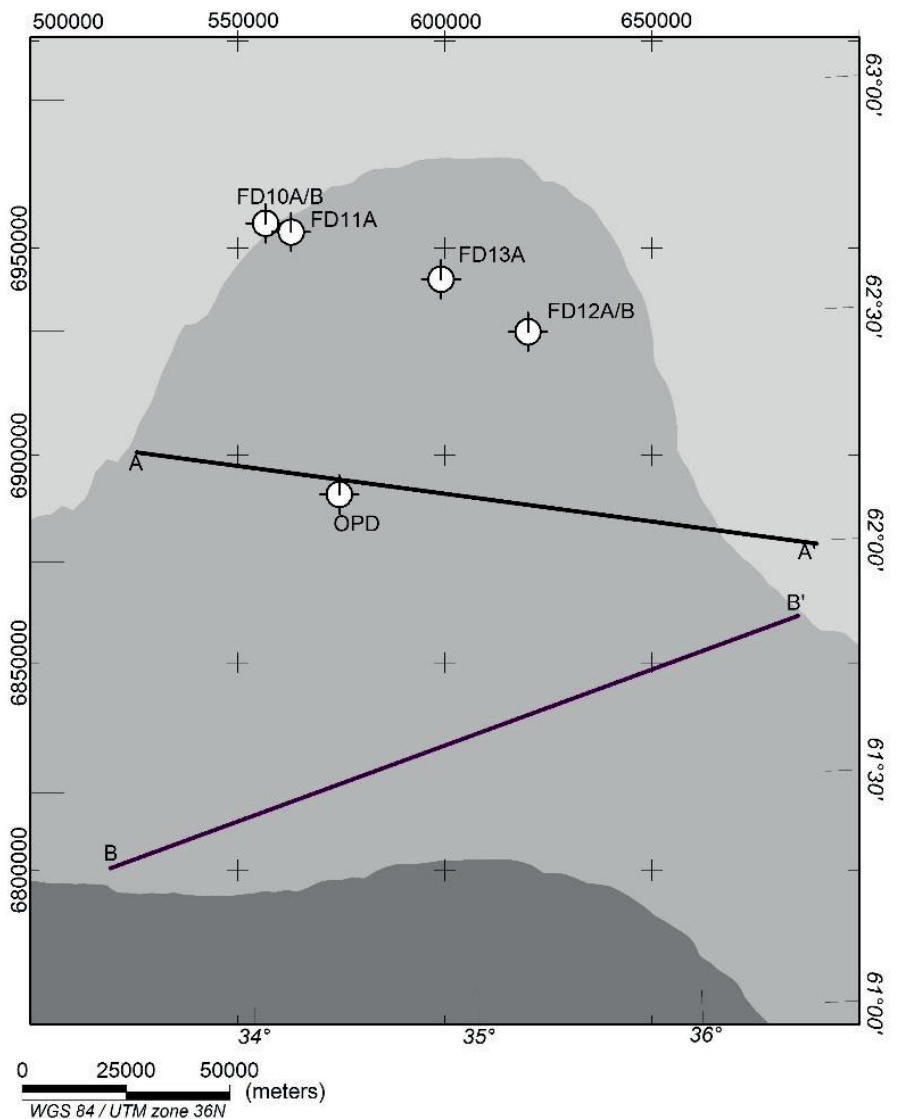

Figure 5. Moho depth of the study area (Grad et al., 2009). The uncertainty of the depth estimates according to Grad and coauthors is $5 \mathrm{~km}$. 
Table 2. Summary of the drilling projects (FAR-DEEP project, Onega Parametric Drillhole) including the depth of the intersected formations.

\begin{tabular}{lll}
\hline Drillhole & \multicolumn{1}{c}{ Depth } & \multicolumn{1}{c}{ Formation } \\
\hline FAR-DEEP 10A & $0-432 \mathrm{~m}$ & Tulomozero \\
FAR-DEEP 10B & $20.6-278 \mathrm{~m}$ & Tulomozero \\
FAR-DEEP 11A & $2.8-106 \mathrm{~m}$ & Zaonega \\
& $106-436 \mathrm{~m}$ & Tulomozero \\
FAR-DEEP 12AB & $1.6-504 \mathrm{~m}$ & Zaonega \\
FAR-DEEP 13A & $1.6-240 \mathrm{~m}$ & Zaonega \\
Onega Parametric & $0-250 \mathrm{~m}$ & Kalevian \\
Drillhole (OPD) & $250-700 \mathrm{~m}$ & Suisari \\
& $700-2115 \mathrm{~m}$ & Zaonega \\
& $2115-2940 \mathrm{~m}$ & Tulomozero \\
& $2940-3500 \mathrm{~m}$ & Archean basement \\
\hline
\end{tabular}

thickness (Fig. 5). In the compilation, crustal thickness ranges from 40 to $45 \mathrm{~km}$ in the Onega Basin with an uncertainty of $5 \mathrm{~km}$.
In the summary report for the Onega Basin, Glushanin et al. (2011) shows a complete Moho model that varies from 30 to $45 \mathrm{~km}$ in the study area. Such large differences in crustal thickness, would be expected to be reflected in the gravity signal as well. The Bouguer anomaly is, however, quite constant and does not show any major long-wavelength changes. In addition, as the data for the compilation of Glushanin et al. (2011) are not accessible, we adopt the crustal thickness after Grad et al. (2009).

\section{D model}

The gravity and magnetic 3D model was developed with the $3 \mathrm{D}$ modelling software IGMAS+ (Interactive Geophysical Modelling ASistant) (e.g., Götze \& Lahmeyer, 1988; Götze, 2013). The model area has an extension of $250 \mathrm{~km}$ from north to south, $200 \mathrm{~km}$ from east to west and a total depth of $120 \mathrm{~km}$. To avoid edge effects of the calculated magnetic and gravity fields, the margin of the model area was extended by about $500 \mathrm{~km}$ in each direction. We define the geometry of the model on 32 parallel sections, which are aligned perpendicular to the general strike trend of approximately $150^{\circ}$ (NNWSSE) (Fig. 6). The distance between neighbouring sections ranges from 8 to $20 \mathrm{~km}$ depending on the size

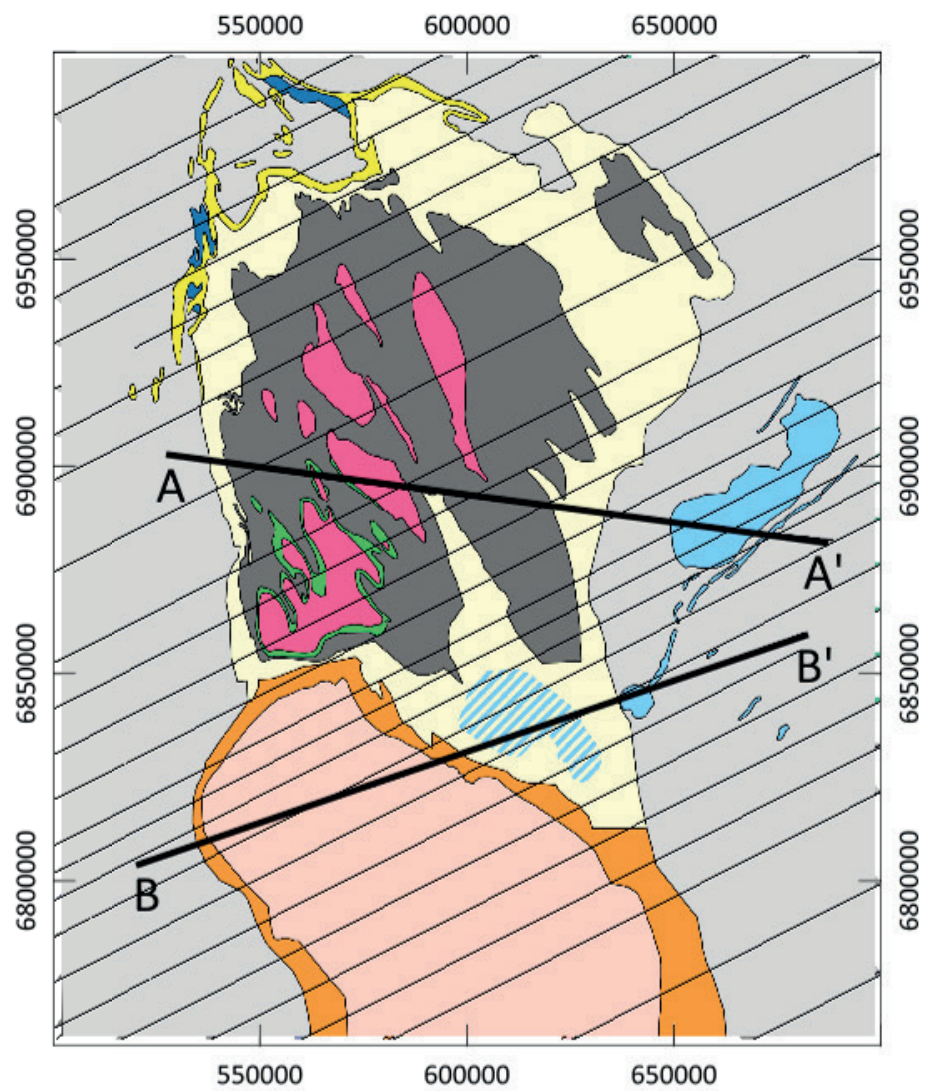

Figure 6. Overview of the geological units and the location of the vertical sections in the final model. The varying distances of the sections are chosen to select the best representation of the surface geology. The complete $3 D$ model is available as Electronic Supplement A. 
Table 3. List of the geological bodies used in the final model including the assigned rock densities and magnetic properties. The parameters are within the range given in Table 1.

\begin{tabular}{lcc}
\hline Geological unit & $\begin{array}{c}\text { Density } \\
{\left[\mathrm{g} / \mathrm{cm}^{3}\right]}\end{array}$ & $\begin{array}{c}\text { Susceptibility } \\
{[\mathrm{SI}]}\end{array}$ \\
\hline Mantle & 3.3 & 0 \\
Lower crust & 3.0 & 0.005 \\
Middle crust & 2.85 & 0.01 \\
Dense upper crust (west) & 2.8 & 0.075 \\
Dense upper crust (east) & 2.75 & 0.1 \\
Upper crust (centre) & 2.7 & 0.12 \\
Nappe structure & 2.7 & 0.075 \\
Sumian intrusions & $3.2 / 3.0$ & $0.15 / 0.025$ \\
Sumian + Sariolian (Kumsa region) & 3.1 & 0.08 \\
Tulomozero formation & 2.75 & 0.001 \\
Zaonega formation & 2.85 & 0.05 \\
Suisari formation & 2.85 & 0.005 \\
Kalevian Horizon & 2.6 & 0.001 \\
Petrozavodsk formation & 2.7 & 0.001 \\
Shoksha formation & 2.7 & 0.001 \\
Gabbroic Sills & 3.1 & 0.05 \\
\hline
\end{tabular}

of the geological body. Through automatic triangulation, the modelling planes are connected to define $3 \mathrm{D}$ objects (polyhedrals).

In order to calculate gravity and magnetic fields, we assigned densities and magnetic susceptibilities to every 3D body. The parameters for the Archaean basement and the Tulomozero, Zaonega, Suisari and Kondopoga formations are well known from the drillcores. Because values are highly variable within individual formations, densities and susceptibilities were averaged over depth. For the other horizons in the Onega Basin, we assigned typical rock properties in agreement with studies for the Fennoscandia Shield (Koslovskaya et al., 2004; Ebbing et al., 2012). The full list of rock densities is given in Table 3. To simplify the model, the Kondopoga and the Vashozero formations were merged to the Kalevian horizon because of their similar petrophysical properties. Moreover, the Glubokozero, Kumsa and Paljeozero formations were combined into one horizon in the Kumsa area. We did not incorporate the Jangzero and the Medvezhegorsk formations in the model, since their total thickness of less than $50 \mathrm{~m}$ is too low to have a significant effect on the magnetic and gravity field. The geometry of the volcano-sedimentary formations was based mainly on the geological information and the two profiles shown in Fig. 1 as well as on drillcore data.
As mentioned before, data concerning the deeper crustal structure are very limited. That is why we assumed a typical crustal subdivision into a lower, middle and upper crust (e.g., Ebbing et al., 2012). The main reason is to present the increase of crustal density with depth (pressure) and to have a realistic density contrast at the Moho boundary.

\section{Results}

The model is presented in Figs. 7-10.

The shallow structure of the model is in agreement with previous geological models.

The Moho boundary in the model is flat, only in some parts the depth was varied by a few kilometres $(\leq \pm 5 \mathrm{~km})$ in line with the uncertainties of the constraining data.

In contrast, the thickness of the individual crustal layers is more variable (lower crust $5-20 \mathrm{~km}$, middle crust 2-30 $\mathrm{km}$, upper crust $8-20 \mathrm{~km}$ ) to reproduce the regional, long-wavelength part of the gravity field, e.g., the broad gravity lows in the northern and southeastern parts of the Onega Basin were modelled by applying a thin lower and middle crust in these areas. An alternative would have been to change lateral variations of densities in the model. However, due to the lack of constraints and the small amplitude of the gravity field, that was deemed by us to be too complex.

In order to address the sources of both the magnetic and the gravity field, we had to introduce a lateral subdivision of the upper crust. In the central basin the basement has a normal density of $2.7 \mathrm{~g} / \mathrm{cm}^{3}$, but a high susceptibility of 0.12 (SI) leading to the magnetic anomaly high. In the eastern and western parts, the susceptibility is much lower, but the density is slightly higher $\left(2.75-2.85 \mathrm{~g} / \mathrm{cm}^{3}\right)$. The angle of dip of these outer crustal blocks towards the basin interior ranges from $20^{\circ}$ to $70^{\circ}$.

In addition, we added a nappe-like structure with a lower susceptibility overlying the strongly magnetised layer in the eastern part of the basin to model the magnetic anomaly lows (Fig. 7).

The most distinct gravity anomaly high, which also correlates with a low-amplitude magnetic anomaly high, can be found in the east of the Onega Basin. It is related to a mafic intrusion from the Sumian with a thickness of up to $2 \mathrm{~km}$. We assigned a high density of $3.2 \mathrm{~g} / \mathrm{cm}^{3}$ as well as a high susceptibility of 0.15 (SI), only slightly higher as measured on the drillcores. A similar body is located in the central basin underneath the Tulomozero formation, but in this case a magnetic low is observable. Here, we applied a magnetic susceptibility of 0.025 (SI) 

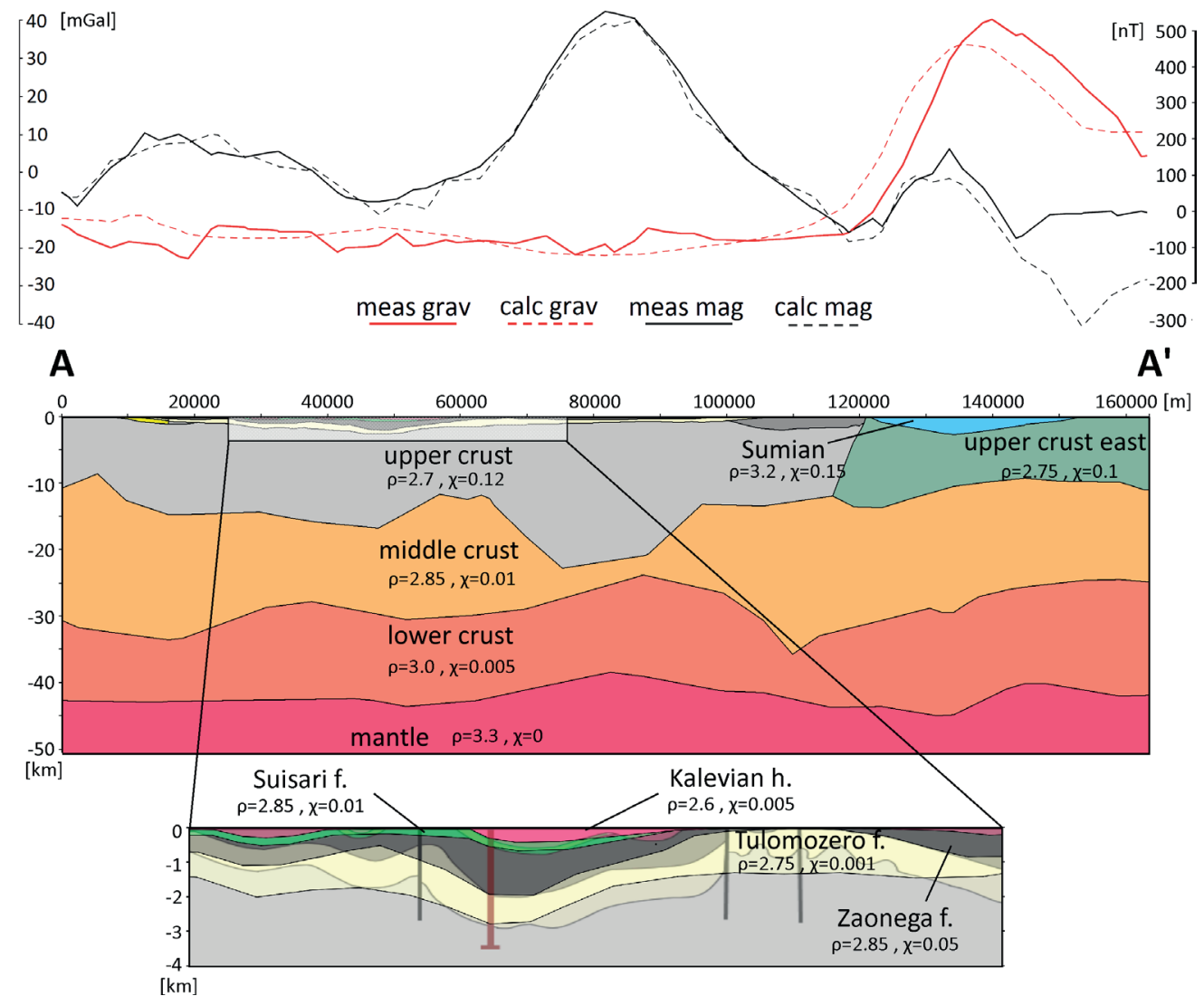

Figure 7. Profile A-A' in the northern Onega Basin with the modelled and the observed Bouguer and magnetic anomalies (top) and a detailed view of the modelled volcano-sedimentary formations. The modelled section and profile A-A'are superimposed in the bottom panel. The model differs in some parts from the geological profile, but the general structure is similar. The used values for the density $\rho$ and susceptibility $\chi$ are added to each unit.
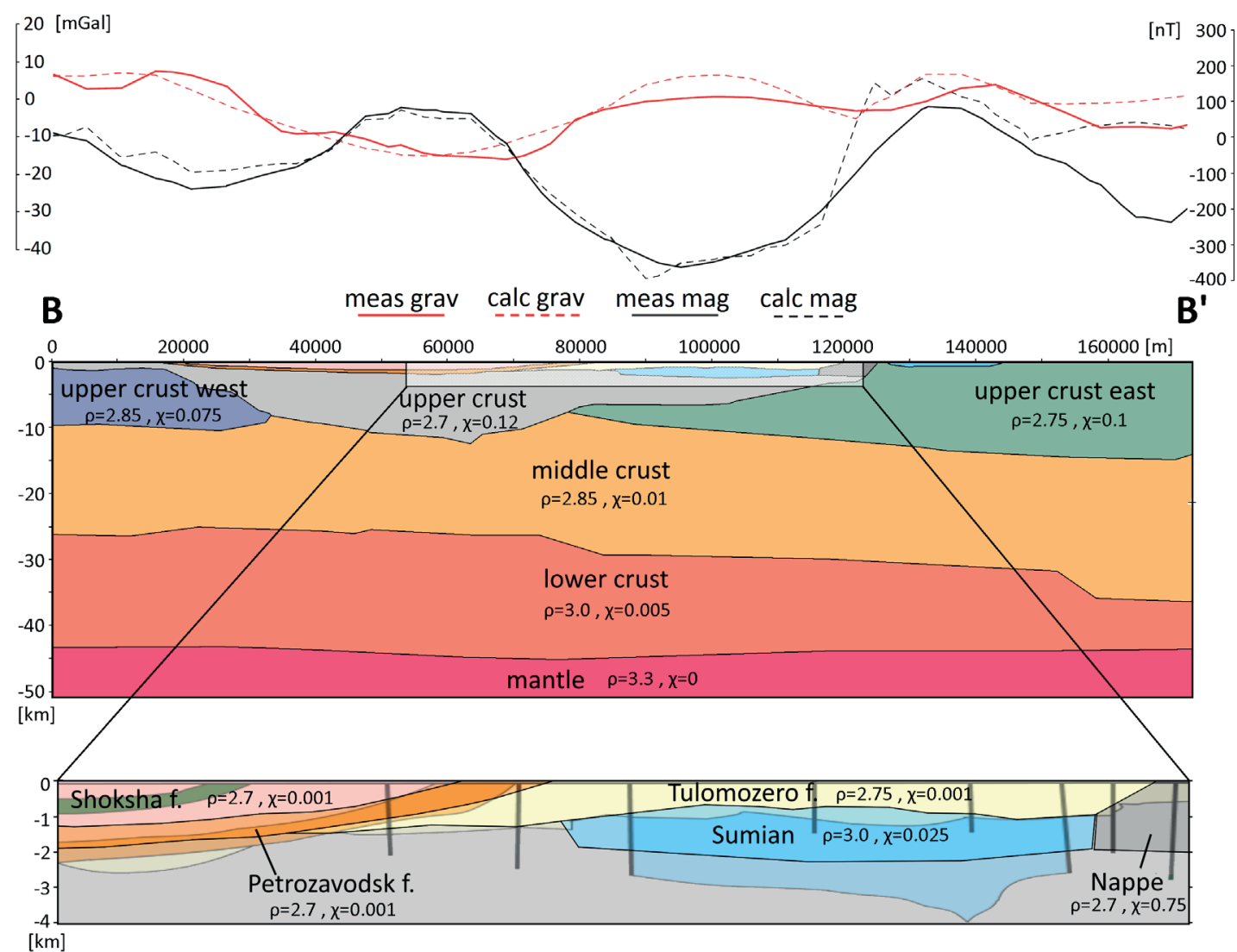

Figure 8. Profile B-B' in the northern Onega Basin with the modelled and the observed Bouguer and magnetic anomalies (top) and a detailed view of the modelled volcano-sedimentary formations. The modelled section and profile B-B' (Fig. 1) are superimposed in the bottom panel. 

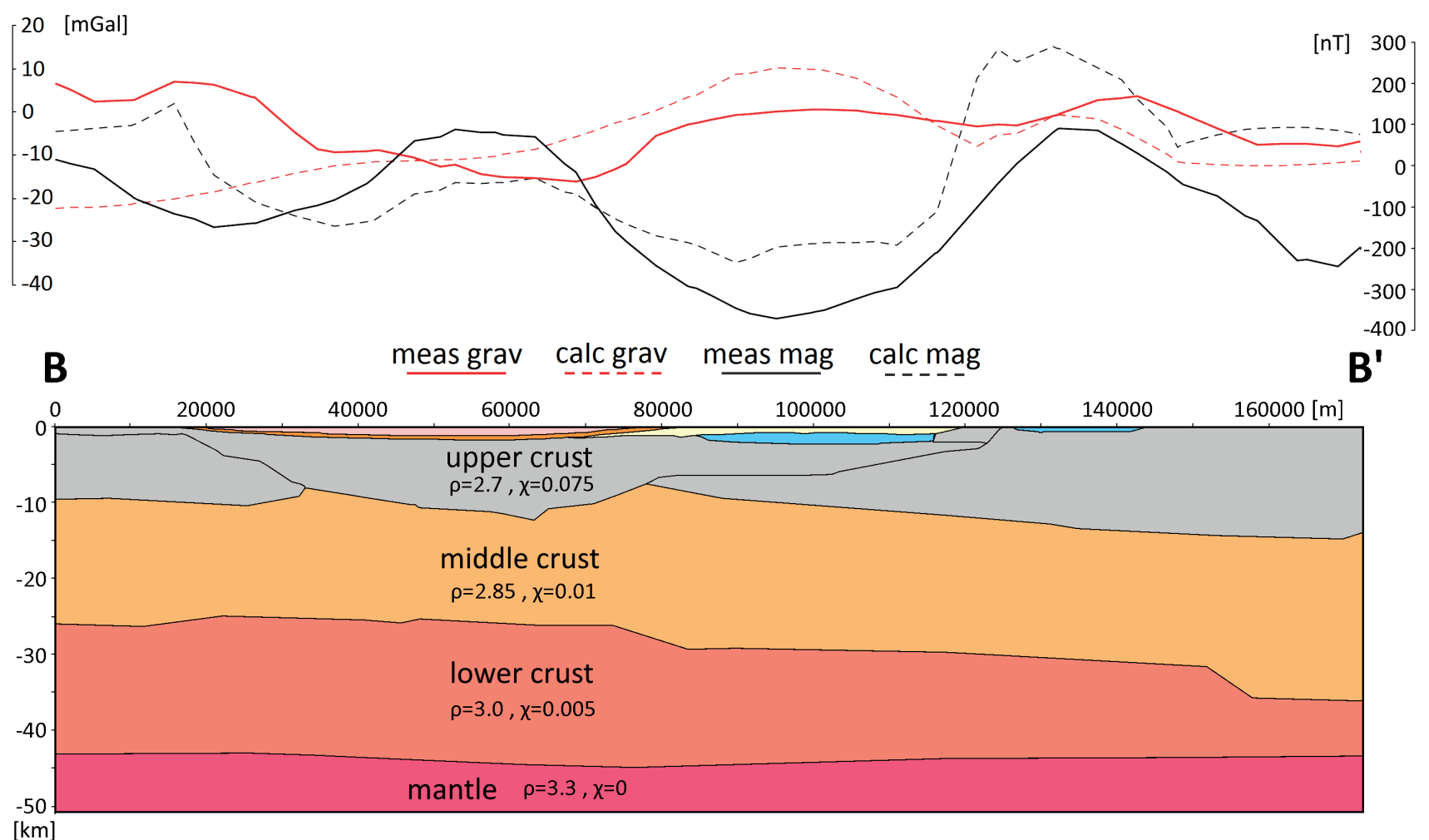

Figure 9. Profile B-B' in the northern Onega Basin with the modelled and the observed Bouguer and magnetic anomalies. The density and susceptibility are now homogeneously distributed in the upper crust. As a result the fit of the anomalies is worse.

\section{A) Gravity residual}

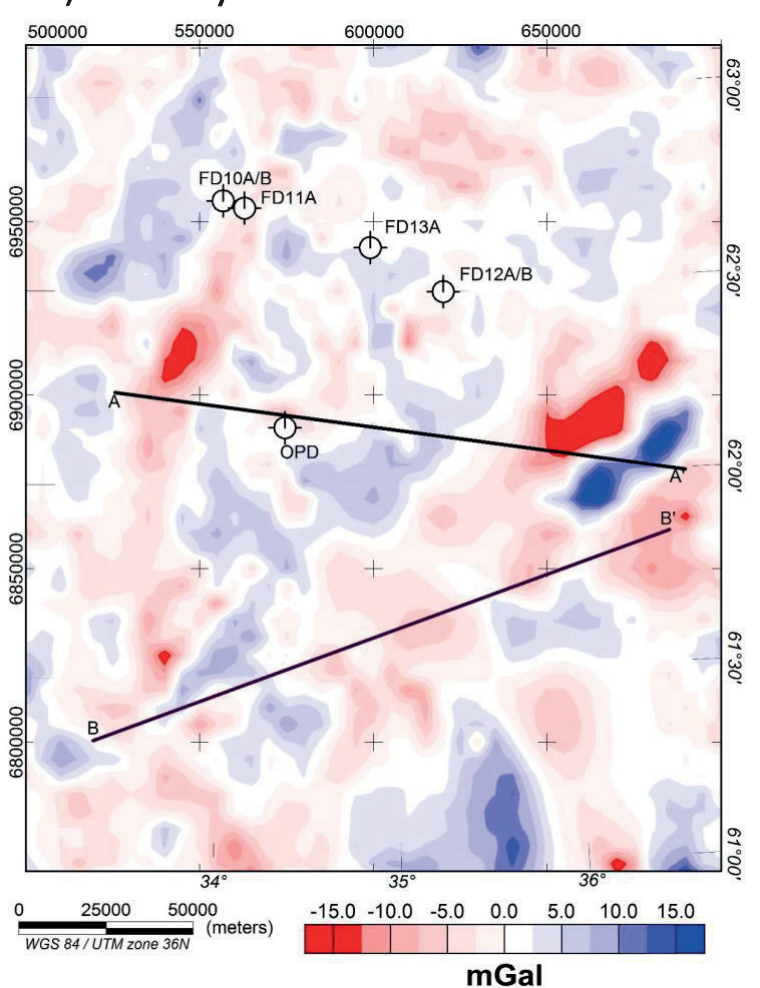

B) Magnetic residual

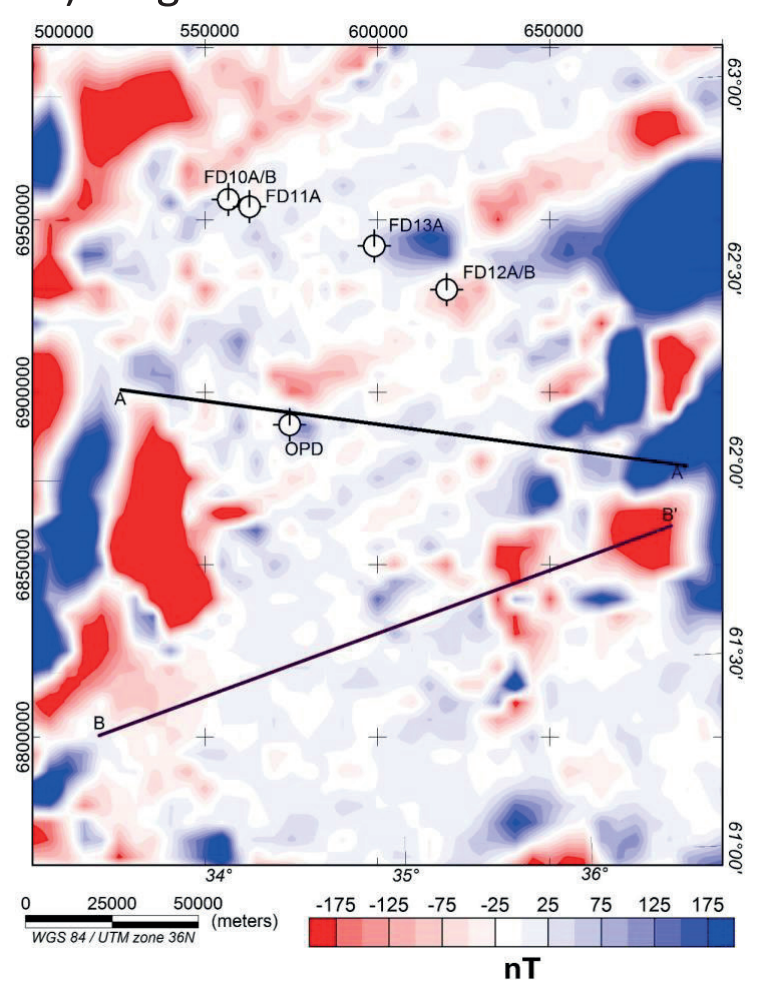

Figure 10. (A\& B) Differences between modelled and observed gravity and magnetic anomalies, respectively. 
and a density of $3.0 \mathrm{~g} / \mathrm{cm}^{3}$. Further gravity and magnetic highs associated with magmatic intrusions are situated in the Kumsa area and on top of the Shoksha formation, where we assigned similar parameters.

The misfit of the modelled and observed data is shown in Fig. 10. Especially in the central basin, the anomaly fit can be regarded as satisfying. The correlation coefficient between the modelled and the observed Bouguer anomaly is 0.941 , and for the magnetic field 0.74 .

In general, the largest differences are located in the outer parts of the study area, where only limited data about the geological structure and composition are available.

\section{Discussion}

The presented 3D model is, of course, not the only possible model to explain the gravity and magnetic data. We tried to incorporate as much geological information as possible, while at the same time keeping the model as simple as possible.

For illustration, we show in Fig. 9 a profile of a model with homogeneous upper crust. In this case, the fit of the gravity and magnetic field is worse than in the preferred 3D model and some anomalies cannot be explained at all. Even though the models appear quite different, the density difference between the two set-ups is within the uncertainty range normally given by seismic-derived densities. Hence, in terms of parameters, they are both reasonable. For the magnetic susceptibility, the differences can be perceived larger, but are still within a reasonable range based on the petrophysical measurements. However, the lateral subdivision of the upper crust is certainly an interpretation in line with the geological evolution of the basin. The high magnetisation in the centre probably resulted from crustal extension and the development of the continental basin during the early Palaeoproterozoic. At that time, the crust was highly affected by volcanic activity, which led to the widespread development of magmatic intrusions with high susceptibility. It is yet uncertain how thick this highly magnetised layer really is. The OPD is the only drilling that has penetrated about $600 \mathrm{~m}$ of basement underneath the volcano-sedimentary formation, but only down to a total depth of $3500 \mathrm{~m}$. In the absence of any other kind of information it was the geophysical data that helped to resolve the structure, even though the total thickness is very uncertain.

However, the shallow structure of the model is in good agreement with geological models and the borehole data. An unexpected result was that the Sumian magmatic complexes appear to be quite heterogeneous and are characterised by a range of density and susceptibility. A possible explanation is that the two-modelled units developed were affected either during their formation or afterwards by processes altering their evolution, as for example thermal pulses.

There are still some uncertainties about the deeper structure in the Onega region, which might affect the modelling results. The Moho depth compilation from Grad et al. (2009) shows only uncertainties in the range of $5 \mathrm{~km}$. The results of Glushanin (2011) differ beyond this uncertainty, but due to a non-availability of data, the sources cannot be determined. A dedicated seismic campaign might shed some light on the internal basement structure and verify the internal build-up of the crust.

For the near-surface, the petrophysical measurements have shown that densities and magnetic susceptibilities can vary quite considerably within the formations and such details would be preferred for incorporating into the model. However, some of the geological units were either not integrated at all or merged with each other with averaged properties due to their limited extension or thickness. The available potential field data therefore do not allow a more detailed analysis, but local high-resolution gravity and magnetics could illuminate such details, even providing the possibility to detect remanent magnetisation. The detection of remanent magnetisation might be helpful to understand the Palaeoproterozoic development of the basin in more detail, especially in combination with more detailed analysis of the FAR-DEEP drillcores.

\section{Conclusions}

A structural 3D model of the Onega Basin has been developed based on geophysical data and data provided by two major drilling projects. The model includes the main geological structures of the study area. Based on the model we conclude that:

(1) The main gravity and magnetic anomalies are associated with known geological bodies. In particular, magmatic rocks are sources for the prominent magnetic and gravity highs. The thicknesses of the volcano-sedimentary formations are in agreement with the results of previous studies and only slight adjustments were necessary in order to model the magnetic and gravity anomalies.

(2) The Sumian magmatic complexes appear to split into two domains, which indicates either changes or alteration during or after their formation.

(3) The observed magnetic and gravity anomalies indicate a subdivision of the upper crust into at least three parts. In the centre, the crust is highly magnetised and has a lower density, whereas the crust at the eastern and western edges of the region has a higher 
density and a lower magnetic susceptibility. The high magnetisation in the central part probably resulted from crustal extension and the development of the continental basin during the early Palaeoproterozoic, which led to widespread magmatism.

(4) The deep structure beneath the basin remains largely unknown. Few seismic constraints are available. The low-amplitude range of the free-air and Bouguer anomalies does not point to any large lateral changes in the lower crust or in crustal thickness.

Acknowledgements. We thank the editor, Trond Slagstad and two reviewers, Peter Hedin and Christine Fichler, for their critical and constructive remarks, which helped us to improve the manuscript.

\section{References}

Andersen, O.B., Knudsen, P. \& Berry, P. 2010: The DNSC08GRA global marine gravity field from double retracked satellite altimetry. Journal of Geodesy 3, 191-199. https://doi.org/10.1007/s00190-009-0355-9.

Blättler, C.L., Claire, M.W., Prave, A.R., Kirsimäe, K., Higgins, J.A., Medvedev, P.V., Romashkin, A.E., Rychanchik, D.V., Zerkle, A.L., Paiste, K., Kreitsmann, T., Millar, I.L., Hayles, J.A., Bao, H., Turchyn, A.V., Warke, M.R. \& Lepland, A. 2018: Two-billion-year-old evaporates capture Earth's great oxidation. Science 360, 320-323. https://doi.org/10.1126/science.aar2687.

Berry, P.A.M., Smith, R.G. \& Benveniste, J. 2010: ACE2: The New Global Digital Elevation Model. International Association of Geodesy Symposia 135, 231-237. https://doi.org/10.1007/978-3-642-10634-7_30.

Črne, A.E., Melezhik, V.A., Lepland, A., Fallick, A.E., Prave, A.R. \& Brasier, A.T. 2014: Petrography and geochemistry of carbonate rocks of the Paleoproterozoic Zaonega Formation, Russia: Documentation of 13 C-depleted non-primary calcite. Precambrian Research 240,79-93. https://doi.org/10.1016/j.precamres.2013.10.005.

Ebbing, J., England, R.W., Korja, T., Lauritsen, T., Olesen, O., Stratford, W., Weidle, C. 2012: Structure of the Scandes lithosphere from surface to depth. Tectonophysics 536-537, 1-24. https://doi.org/10.1016/j.tecto.2012.02.016.

Gaina, C., Werner, S.C. \& CAMP-GM group. 2011: Chapter 3 CircumArctic mapping project: New magnetic and gravity anomaly maps of the Arctic. Geological Society Memoirs 35, 39-48.

Glushanin, L.V., Sharov, N.V. \& Shchptsov, V.V. 2011: Palaeoproterozoic Onega Structure (Geology, tectonics, deep structure and mineralogeny). Karelian Research Centre, 431 pp.

Gorbatschev, R. \& Bogdanova, S. 1993: Frontiers in the Baltic Shield. Precambrian Research 64, 3-21. https://doi.org/10.1016/0301-9268(93)90066-B.

Götze, H.J. 2013: Potential Methods and Geoinformation Systems. In Freeden W., Nashed M., \& Sonar T. (eds): Handbook of Geomathematics, Springer, Berlin, Heidelberg, pp. 1-21.

Götze, H.J. \& Lahmeyer, B. 1988: Application of three-dimensional interactive modeling in gravity and magnetics. Geophysics 53, 1096-1108. https://doi.org/10.1190/1.1442546.

Grad, M., Tiira, T. \& ESC Working Group 2009: The Moho depth map of the European Plate. Geophysical Journal International 176, 279-292.

Holland, H.D. 2006: The oxygenation of the atmosphere and oceans. Philosophical Transactions of the Royal Society B 361, 903-915. https://doi.org/10.1098/rstb.2006.1838.
Kozlovskaya, E., Elo, S., Hjelt, S.E., Ylniemi, J., Pirttijärvi, M. \& SVEKALAPKO Seismic Tomography Working Group 2004: 3 -D density model of the crust of southern and central Finland obtained from joint interpretation of the SVEKALAPKO crustal P-wave velocity models and gravity data. Geophysical Journal International 158, 827-848

Krupenik, V.A., Akhmedov, A.M. \& Sveshnikova, K.Y. 2011: Structure of the section based on OPB drilling. In Glushanin, L.V., Sharov, N.V. \& Shchptsov, V.V. (eds.): The Onega Palaeoproterozoic structure (Geology, tectonics, deep structure and mineralogy), Karelian Research Centre, pp. 172-189.

Kulikov, V.S., Medvedev, P.V. \& Golubev, A.I. 2011: Summary geological map of the Onega Structure. In Glushanin, L.V., Sharov, N.V. \& Shchptsov, V.V. (eds.): The Onega Palaeoproterozoic structure (Geology, tectonics, deep structure and mineralogy), Karelian Research Centre, pp. 19-23.

Kump, L.R., Junium, C., Arthur, M.A., Brasier, A., Fallick, A., Melezhik, V., Lepland, A., Črne, A.E. \& Genming, L. 2011: Isotopic Evidence for Massive Oxidation of Organic Matter Following the Great Oxidation Event. Science 334, 1694-1696. https://doi.org/10.1126/science.1213999.

Kuznetsov, A.B., Gorokhov, I.M., Melezhik, V.A., Melnikov, N.N., Konstantinova, G.V. \& Turchenko, T.L. 2012: Strontium isotope composition of the lower proterozoic carbonate concretions: The Zaonega Formation, Southeast Karelia. Lithology and Mineral Resources 47,319-333. https://doi.org/10.1134/S0024490212030066.

Lahtinen, R., Garde, A.A. \& Melezhik, V.A. 2008: Paleoproterozoic evolution of Fennoscandia and Greenland. Episodes 31, 20-28.

Melezhik, V.A., Fallick, A.E., Filippov, M.M., Lepland, A. \& Rychanchik, D.V. 2009: Petroleum surface oil seeps from Palaeoproterozoic petrified giant oilfield. Terra Nova 21, 119-126. https://doi.org/10.1111/j.1365-3121.2009.00864.x.

Melezhik, V.A., Lepland, A., Romashkin, A.E., Rychanchik, D.V., Mesli, M., Finne, T.E., Conze, R. \& FAR-DEEP Scientists 2010: The Great Oxidation Event Recorded in Paleoproterozoic Rocks from Fennoscandia. Scientific drilling: reports on deep earth sampling and monitoring 9, 23-29.

Melezhik, V.A., Prave, A.R., Fallick, A.E., Kump, L.R., Strauss, H., Lepland, A. \& Hanski, E.J. (eds.) 2013a: Reading the Archive of Earth's Oxygenation: Volume 1: The Palaeoproterozoic of Fennoscandia as Context for the Fennoscandian Arctic Russia Drilling Early Earth Project, Springer, pp. 490.

Melezhik, V.A., Prave, A.R., Hanski, E.J., Fallick, A.E., Lepland, A., Kump, L.R. \& Strauss, H. (eds.) 2013b: Reading the Archive of Earths Oxygenation: Volume 2: The Core Archive of the Fennoscandian Arctic Russia - Drilling Early Earth Project, Springer, pp. 554.

Pavlis, N.K., Holmes, S.A., Kenyon, S.C., Factor, J.K., 2012: The development and evaluation of the Earth Gravitational Model 2008 (EGM2008). Journal of Geophysical Research 117, B04406. https://doi.org/10.1029/2011JB008916.

Slabunov, A.I., Lobach-Zhuchenko, S.B., Bibikova, E.V., Balagansky, V.V., Sorjonen-Ward P., Volodichev O.I., Shchipansky, A.A., Svetov, S.A., Chekulaev, V.P., Arestova, N.A. \& Stepanov, V.S. 2006: The Archean of the Baltic Shield: Geology, Geochronology, and Geodynamic Settings. Geotectonics 40, 409-433. https://doi.org/10.1134/S001685210606001X.

Symons, D.T.A. 1975: Huronian glaciation and polar wander from the Gondwana Formation. Geology 3, 303-306. https://doi.org/10.1130/0091-7613(1975)3<303:HGAPWF>2.0.CO;2.

Young, G.M. 1991: The geological record of glaciation: relevance to the climate history of Earth. Geoscience Canada 18, 100-108.

Zhao, G., Cawood, P.A., Wilde, S.A \& Sun, M. 2002: Review of global 2.1-1.8 Ga orogens: implications for a pre-Rodinia supercontinent. Earth-Science Reviews 59, 125-162. https://doi.org/10.1016/S0012-8252(02)00073-9. 